\title{
Tacit Knowledge Sharing Behavior, Within A Relational Social Capital Framework, In A South African University Of Technology
}

\author{
Carol Smith, D. Tech., Durban University of Technology, South Africa \\ Marie de Beer, Ph.D., Durban University of Technology, South Africa \\ Roger Bruce Mason, Ph.D., Durban University of Technology, South Africa
}

\begin{abstract}
The sharing of tacit knowledge is an important influence on the development of intellectual capital in a University of Technology but whereas its effects are clear in a business context, they have been absent from studies in the context of higher education.

This study integrated relational social capital and reasoned action theory to construct a model to investigate the factors that predict an individual's intention to share tacit knowledge. Specifically, it examined the relationship between relational social capital in terms of trust (affect and cognitivebased trust), shared norms and values (including social norms and norms of social support and reciprocity) and the individual's attitude towards sharing tacit knowledge. It further examined the relationship between the individual's attitude, their perceived norms and perceived behavioral control over the sharing of tacit knowledge and their intention to share tacit knowledge.

A hypothesized, theoretical model of the individual's intention to share tacit knowledge was developed. This model was found to be a poor fit to the data and an alternative model was developed which was found to be a good fit to the data. This study incorporated nine research interviews and five hundred and fifty four questionnaires.

Relational social capital was found to be significant for predicting individuals' intentions to share tacit knowledge but the reasoned action variables were found to be less significant, particularly perceived behavioral control over the sharing of tacit knowledge, indicating the need for further research.
\end{abstract}

Keywords: Social Capital; Theory of Reasoned Action; Tacit Knowledge Sharing; Trust; Norms; Attitude

\section{INTRODUCTION}

$\mathscr{Q}$ niversities of Technology use tacit knowledge to build their knowledge base. They are an important site to study the sharing of tacit knowledge, as like business organizations, they encounter the problem of how to effectively create and share tacit knowledge (Lam, 2000). The creation and sharing of tacit knowledge is influenced by relational social capital and the individual's intention to share tacit knowledge. This creation is an important influence on the production of intellectual capital, as intellectual capital is formed by the accumulation of useful tacit and explicit knowledge.

The primary research question that was explored in this study was "how does relational social capital influence an individual's intention to share tacit knowledge?" This is a crucial question because if social capital influences an individual's intention to share tacit knowledge, universities can institute business and managerial practices that promote social capital and the sharing of tacit knowledge within the university. These practices will lead to the development and transfer of intellectual capital which is the core business of a university. 
This is important as a university's competitive advantage is dependent upon intellectual capital, its unique intangible resource and its ability to utilize this resource effectively. Today, a major part of economic value creation is based on intangible resources. Research into the formation of intellectual capital gives intangibles 'a body' and facilitates the use of intangibles for successful business and knowledge management. However, most universities still do not understand how intellectual capital is formed and how tacit knowledge is shared amongst its employees. In addition they lack appropriate business management practices to effectively utilize their intangible resources to create future value.

The problem of knowledge and intellectual capital management is complex because it can be difficult to measure and manage intangible assets as the degree of tacitness in the transferred knowledge depends on the influence of various intangible factors such as personal beliefs, trust, experience, values and norms (Inkpen and Pien, 2006). Inherently tacit knowledge resides within individuals, specifically in the employees who access and apply knowledge in carrying out their work tasks. Consequently, the movement of knowledge into operational routines and business practices and the resultant accumulation of intellectual capital are ultimately dependent upon the individual's intention to share knowledge and knowledge sharing behavior.

This paper is organized into six sections including this introduction. The next section provides a theoretical review of the literature to identify antecedents to employees' attitudes towards tacit knowledge sharing behavior and their intention to share tacit knowledge. The third section provides a conceptual framework depicting the research model and outlines the research hypotheses characterizing the relationships depicted in the model. The fourth section describes the research methodology and analysis, while the fifth section discusses the results, their significance and recommendations. Finally, the last section presents the conclusion.

\section{LITERATURE REVIEW}

\section{Tacit Knowledge}

This study examined an individual's intention to share tacit knowledge. The specific type of tacit knowledge that was studied related to work experience, specifically 'know-what' and 'know-how'. 'Know-what' referred to the basic mastery of a discipline that professionals achieve through education and training (Seonghee and Boryung, 2008). 'Know-how' referred to procedural knowledge about a business process and the individual's capability to perform an action with an understanding of why the action is appropriate in the particular context, (i.e., action skill or applied competence), (Baldwin, Pierce, Joines and Farouk, 2011). Furthermore, it included an understanding of how to effectively execute appropriate action and when and under what circumstances it would be appropriate to take such action. Thus, tacit knowledge represented both the capability to perform an action and an explicit understanding of why the action is appropriate in a particular context.

\section{Relational Social Capital}

Nahapiet and Ghoshal's (1998) definition and conceptualization of relational social capital was applied in this research. They define social capital as "the sum of the actual and potential resources embedded within, available through, and derived from the network of relationships possessed by an individual or social unit" (Nahapiet and Ghoshal, 1998: 243).

Relational social capital describes the personal qualities of interpersonal relationships (Bolino, Turnley and Bloodgood, 2002). It is concerned with expectations and obligations as central features of social capital and captures the norms and quality of dyadic relations which are determined by the history of interactions between individuals. It is similar to Adler and Kwon's (2002) concept of 'goodwill' and in Nahapiet and Ghoshal's (1998) opinion, includes trust, norms, obligations and identification.

Hazleton and Kennan (2000) mention three features of relational social capital as follows: firstly, it is the primary relational feature of social capital, secondly, it includes identification, which refers to the extent to which actors view themselves as connected to other actors and finally the third feature is the degree of social system closure. The effect of system closure is the emergence of observable norms. 
According to Chow and Chan (2008) relational social capital focuses on the particular relations people have, such as respect and friendship that influence their behavior. It is through these ongoing personal relationships that people fulfill such social motives as sociability, approval and prestige. For example, two individuals may occupy equivalent positions in similar network configurations, but if their personal and emotional attachments to other network members differ, their actions also are likely to differ in important respects. For instance, although one person may choose to stay in a university because of an attachment to fellow workers, despite economic advantages available elsewhere, another without such personal bonds may discount working relationships in making career moves.

\section{The Reasoned Action Approach}

The theory of reasoned action (Fishbein and Ajzen, 2010) may be applied to tacit knowledge sharing in the following way: attitudes towards the sharing of tacit knowledge are determined by behavioral beliefs, specifically beliefs of outcome evaluation and beliefs about the specific consequences of behavior multiplied by the outcome evaluation. Personal outcome beliefs and expectations about the sharing of tacit knowledge may lead to a positive or a negative attitude towards the sharing of tacit knowledge. Positive attitudes occur if the individual perceives that some benefit will occur if tacit knowledge is shared. Negative attitudes occur if there is a perception that the sharing of tacit knowledge will incur personal costs. Perceived norms are determined by an individual's normative beliefs, specifically the individual's beliefs about the social expectations of specific others multiplied by the motivation to conform to them. Perceived behavioral control beliefs leads to the perception that one has or does not have the ability to share tacit knowledge.

The theory of reasoned action (Fishbein and Ajzen, 2010) specifies that once attitudes, perceived norms and perceived behavioral control beliefs have been formed they are directly accessible and available to guide intentions and behavior. Specifically, in combination, the individual's attitude towards the sharing of tacit knowledge, their perceived norms with regards to the sharing of tacit knowledge, and their perception of behavioural control over tacit knowledge sharing behavior leads to the formation of a behavioral intention, or a readiness to share tacit knowledge. As a general rule, the more favorable the attitude and perceived norm, and the greater the perceived behavioral control, the stronger should be the person's intention to share tacit knowledge. Perhaps more important, if people believe that they do not have control over the sharing of tacit knowledge, they may not form strong behavioral intentions to perform it, even if they hold positive attitudes and perceive strong social pressure to do so.

Research has consistently demonstrated that the theory of reasoned action can effectively model and explain individual human behavior (Chang, 1998; Fishbein and Ajzen, 1981; Kurland, 1995; Mathieson, 1991).

\section{RESEARCH MODEL AND HYPOTHESES}

\section{Research Model}

The results in this paper form part of a larger study in which the effect of the relational, structural and cognitive dimension of social capital on the individual's intention to share tacit knowledge was analyzed. This article reports only the results for relational social capital.

The individual's intention to share tacit knowledge was examined by developing and testing a theoretical model of the antecedent (relational social capital dimensions) and mediating factors (reasoned action dimensions) that influence an individual's intention to share tacit knowledge. The synthesis of the literature suggested that the salient relational social capital factors which influenced tacit knowledge sharing included trust (which included affect-based trust and cognitive-based trust) and shared norms and values (which included social norms and norms of social support and reciprocity).

It should be noted that the final research model deviated from the initially hypothesized model. The structural equation model (SEM) analysis of the initial model revealed a poor fit of the hypothesized model with regard to perceived behavioral control and the individual's intention to share tacit knowledge. This finding has been 
corroborated in a number of studies which have found that the theory of reasoned action displays acceptable correlations but when tested with SEM analysis, performs poorly. Van den Putte (1993) conducted a meta-analysis of one hundred and thirteen studies and Godin and Kok (1996) reviewed fifty six studies and found that the extent to which the models are supported are dependent on the appropriate use of statistical methods. Van den Putte and Hoogstraten (1997) found only one fitting model in a meta-analysis of two hundred articles published between 1991 and 1995. The majority of articles that have found success with the theory of reasoned action have used regressional analysis; few studies have used SEM to assess the theory of reasoned action.

The study's results revealed that the perceived behavioral control questions (Table 2 and 3 - Question 2, 9, 20 and 27) had a low internal consistency (Alpha Coefficient .471), (Cronbach, 1951). The perceived behavioral control questions related to perceived autonomy questions (Table 2 and 3 - Question 2 and 9) had an almost acceptable Alpha Coefficient of .683 (Cronbach, 1951). This finding is in line with other studies findings. Specifically, Fishbein and Ajzen (2010) report that a meta-analysis of ninety studies that used multi-item scales to assess perceived behavioral control reported the average Alpha Coefficient to be about .65 .

The large discrepancy between the theoretical and the observed relations for the perceived behavioral questions (Table 3 - Question 2, 9, 20 and 27) in the SEM analysis led to a revision of the initial proposed model. As a result of the revision process perceived behavioral control was not included in the revised model. The goal of the revision process was a theoretically credible model that is judged acceptable in the empirical model evaluation. Weston and Gore (2006) recommend, in agreement with other researchers (Anderson and Gerbing, 1988; Kline, 2005), that researchers make reasonable, necessary changes to the measurement model when encountering problems with the model.

In addition, as the initial SEM analysis revealed an association between perceived norms and the individual's attitude towards tacit knowledge sharing (standardized regression weight - .520) which was not included in the initial hypothesized model, this relationship was included in the revised model. The relational social capital dimensions of trust, and shared values and norms are discussed in the next section.

Trust

Trust included affect-based and cognitive-based trust as outlined below:

$\underline{\text { Affect-based Trust }}$

Affect-based trust is based upon the individual's view of the other person's values and norms. Lewis and Weigert (1985: 970) refer to affect-based trust as "emotional ties linking individuals, such as friendship, love, or care".

Trust, in the form of affect-based trust affects the individual's attitude towards tacit knowledge sharing. Yang and Farns (2009) study showed that affect-based trust within an organization is an important prerequisite for effective interpersonal tacit knowledge sharing and that managers need to foster the formation of an intensive social network among employees, in order to promote tacit knowledge sharing among staff members.

Leana and Van Buren (1999) comment that universities that are high in social capital will also be high in affect-based trust. They further elaborate that where the university's culture promotes trust and co-operation between individuals, the degree of interactions will rise significantly. In such environments, the tendency to share and exchange knowledge will be high and individuals will eagerly exchange their knowledge.

\section{$\underline{\text { Cognitive-Based Trust }}$}

Cognitive-based trust is based upon the individual's assessment of the other person's competence and reliability in terms of their work function (Rousseau, Sitkin, Burt and Camerer, 1998). Lewis and Weigert (1985: 970) stipulate that trust is 'cognitive-based' because "we cognitively choose whom we will trust under which circumstances and we base the choice on what we take to be good reasons, constituting evidence of trustworthiness". 
The ability to perform work tasks, (i.e., competence), engenders cognitive-based trust with co-workers within the university. Schurr and Ozanne (1985) propose that this is based on the assumption that ability engenders trust that the individual's co-workers will successfully complete a work task. In terms of tacit knowledge sharing, it implies an ability to relay trustworthy information to other staff members. Individuals who report that they trust their co-workers will perceive their co-workers as competent and reliable and will display a more positive attitude towards tacit knowledge sharing.

Shared Norms and Values

There is much evidence showing that the existence of organizational cultural norms and values within an organization fosters knowledge transfer by increasing intimacy and closeness between source and receiver (O'Dell and Grayson, 1998). Such norms according to Nahapiet and Ghoshal (1998: 255) "may be a significant influence on exchange processes, opening up access to parties for the exchange of knowledge and ensuring the motivation to engage in such exchange". Shared norms and values can establish a strong foundation for the creation of intellectual capital becoming, in effect, "expectations that bind" (Kramer and Goldman, 1995). The presence of a supporting university culture that embeds social norms of the sharing of tacit knowledge is necessary to motivate individuals to share tacit knowledge easily and frequently. In this study shared norms and values included social norms, norms of social support and norms of reciprocity. These are discussed in the following section.

\section{$\underline{\text { Social Norms }}$}

Social norms that influence tacit knowledge sharing include "the creation of a sense of involvement and contribution among employees" (O'Dell and Grayson, 1998: 154), the "types of knowledge that are valued" (Leonard-Barton, 1995: 1) and "knowledge-related values such as trust and openness" (Von Krogh, 1998: 133).

\section{$\underline{\text { Norms of Social Support }}$}

Norms of social support may be manifested as altruistic behavior. When individuals in a network work toward a work related goal they often display altruistic behavior, i.e., helping others without expecting anything in return. Altruistic behavior is beneficial for the sharing of tacit knowledge (Wasko and Faraj, 2005).

\section{Norms of Reciprocity}

There is a great deal of empirical evidence for the relationship between reciprocity and knowledge sharing (Bartol and Srivastava, 2002; Dyer and Nobeoka, 2002).

Bock, Zmud, Kim and Lee (2005) confirm that an individual's attitude toward knowledge sharing is driven by anticipated reciprocal relationships regarding knowledge sharing. They contend that "anticipated reciprocal relationships capture employees' desires to maintain ongoing relationships with others, specifically with regard to knowledge provision and reception" (Bock et al., 2005: 93). They argue that "when two individuals are influenced by their social and organizational contexts, especially where knowledge is exchanged, the social exchange relationship is a major determinant of their attitudes" (Bock et al., 2005: 93). Social exchange creates friendships with unspecified obligations. According to them employees who believe their mutual relationships with others can improve through their tacit knowledge sharing are likely to have positive attitudes toward knowledge sharing. The revised model for relational social capital with hypothesized relationships is shown in Figure 1. 
Figure 1. Research Model - Relational Dimension of Social Capital

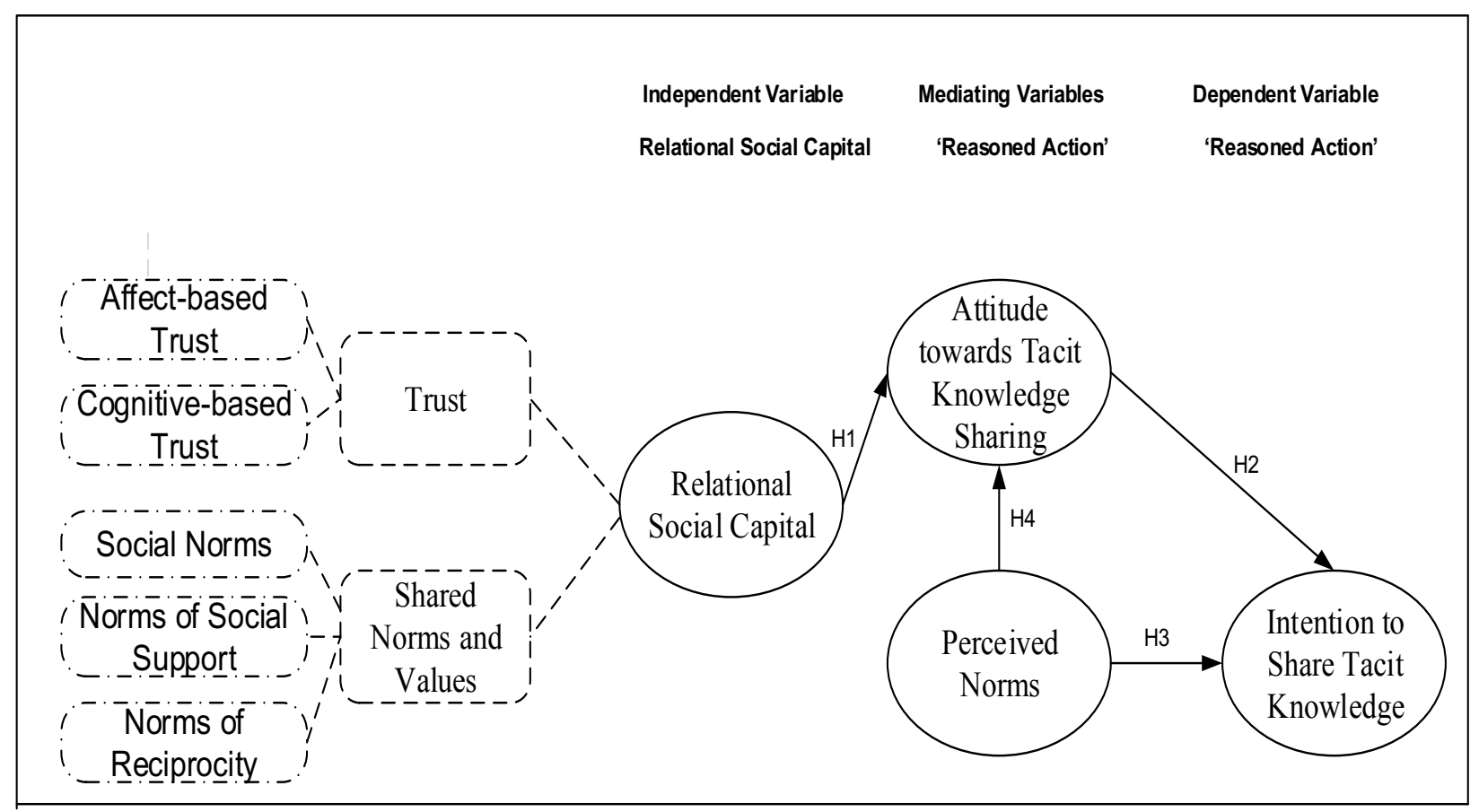

\section{Hypotheses}

Four hypotheses were developed in order to test the relationship between relational social capital and the individual's intention to share tacit knowledge. Many studies have suggested that relational social capital promotes a positive attitude towards tacit knowledge sharing through social interaction (Carley, 1991; Davenport, 1998) and is critical for the transfer of tacit knowledge because it increases information exchange (Kramer, 1999; Nelson and Cooprider, 1996). Thus:

H1: Individuals who report a high level of relational social capital (trust, shared norms and values) will display a positive attitude towards tacit knowledge sharing.

In this study, the reasoned action variables included attitude, perceived norms and intention to share tacit knowledge. Allport (1935) asserts that as people express a more positive attitude toward knowledge sharing, they are more likely to exert more effort to share their knowledge with others within an organisation. Their finding that the attitude towards the behavior leads to a behavioral intention or a readiness to perform the behavior, has been corroborated by many researchers (Armistead and Meakins, 2002; Chang, 1998; Yang, 2010). This leads to the second hypothesis:

H2: An individual's positive attitude towards tacit knowledge sharing positively influences their intention to share tacit knowledge.

Furthermore, the individual's beliefs that important individuals or groups in their lives would approve or disapprove of their sharing their tacit knowledge leads to a perceived norm about the sharing of their tacit knowledge (Ajzen, 1991). The work of Cialdini (2007) suggests that norms can influence behavior by providing evidence as to what will likely be effective and adaptive action. If most others are performing a given behavior, people may assume that it is a sensible thing to do under the circumstances. This is especially true if others are experts with respect to the behavior in question. Cialdini (2007) argues that imitating the actions of others offers an information-processing advantage and a decision-making shortcut when choosing how to behave in a given 
situation. Many studies have found that the individual's perceived norms influence their intention to perform the behavior in question (Bock et al., 2005; Kurland, 1995; Venkatesh and Davis, 2000). Hence,

H3: An individual's perceived norms about tacit knowledge sharing positively influences their intention to share tacit knowledge.

Although Fishbein and Ajzen (2010) do not include a relationship between the person's perceived norms and their attitude toward performing a specific behavior, a number of studies have shown that the individual's perceived norm influences an individual's attitude towards the sharing of tacit knowledge (Shepherd and O' Keefe, 1984; Shimp and Kavas, 1984). Therefore:

H4: An individual's perceived norms about tacit knowledge sharing positively influence their attitude towards tacit knowledge sharing.

\section{RESEARCH METHODOLOGY AND ANALYSIS}

\section{Research Design}

The research design was a case study which consisted of a mixed methods design incorporating qualitative (nine in-depth interviews) and quantitative research (five hundred and ninety questionnaires). This paper only reports the results for the quantitative research. The target population was all salaried staff (academic and administrative) at a University of Technology (refer to Table 1 for a demographic profile of the sample). The measurement constructs and questions were developed by adapting measures that had been validated by other researchers (where reliability, validity and usefulness had been demonstrated) and then modifying them for use in a tacit knowledge sharing context or by converting the definitions of measurements constructs into a survey format.

\section{Measurement and Data Collection}

The relational dimension of social capital included trust (which included affect-based trust and cognitivebased trust) and shared norms and values (which included social norms, and norms of social support and reciprocity). Trust included:

- $\quad$ Affect-based trust, which included perceptions of reciprocal concerns and interpersonal caring (Table 3 Question 1,6 and 17 ) and

- $\quad$ Cognitive-based trust, which included judgment of the other person's competence, reliability, dependability and knowledge ability in the work setting (Table 3 - Question 8, 30 and 32).

Shared norms and values were defined as including:

- Social norms - (i.e., acceptable social behavior with regard to the sharing of tacit knowledge) - (Table 3 Question 10).

- $\quad$ Norms of social support - (i.e., altruistic behavior that relates to the sharing of tacit knowledge) - (Table 3 Question 4 and 23) and

- Norms of reciprocity - (i.e., sharing relationships with others in terms of the sharing of tacit knowledge) (Table 3 - Question 35). 

developed:

The following 'reasoned action' (Fishbein and Ajzen, 2010) measurement constructs and questions were

- $\quad$ Attitude towards tacit knowledge sharing - (Table 3 - Question 19, 25 and 28).

- $\quad$ Perceived norms about tacit knowledge sharing - (Table 3 - Question 3, 15 and 24).

- Perceived behavioral control over the sharing of tacit knowledge. Perceived behavioral control included:

$\circ \quad$ Perceived capacity (Table 3 - Question 2 and 9).

- Perceived autonomy (Table 3 - Question 20 and 27).

- Intention to share tacit knowledge - (Table 3 - Question 18 and 26).

\section{Analysis}

Descriptive and inferential statistics were performed in the analysis using the statistical programs SPSS 19 and Amos, Version 16. In order to test the consistency of the data, the Cronbach (1951) Alpha Coefficient test, the One-Sample t-test, the Sign test, the Wilcoxon Signed Ranks test and the Spearman Rank-Order Correlation Coefficient test were applied to the data.

In addition, Structural Equation Modeling (SEM) including confirmatory factor analysis was performed in order to test and interpret the hypothesized model.

\section{Results}

\section{Demographic Profile}

Table 1 presents a demographic profile of the respondents.

Table 1. Demographic Profile of Respondents

\begin{tabular}{|c|c|c|c|c|c|c|c|}
\hline Measure & Items & Freq. & Percent & Measure & Items & Freq. & Percent \\
\hline \multirow{12}{*}{ Faculty } & Executive Management & 7 & 1.3 & \multirow{10}{*}{$\begin{array}{c}\text { Job } \\
\text { Position }\end{array}$} & Senior Management & 9 & 1.6 \\
\hline & Accounting and Informatics & 33 & 6.0 & & Middle Management & 12 & 2.2 \\
\hline & Applied Science & 41 & 7.4 & & Junior Management & 15 & 2.7 \\
\hline & Arts and Design & 47 & 8.5 & & Professor & 14 & 2.5 \\
\hline & Engineering and the Built & 48 & 8.7 & & Senior Lecturer & 58 & 10.5 \\
\hline & Environment & & & & Lecturer & 180 & 32.5 \\
\hline & Health Sciences & 68 & 12.3 & & Junior Lecturer & 36 & 6.5 \\
\hline & Management Sciences & 66 & 11.9 & & Admin. & 183 & 33.0 \\
\hline & Support - Academic & 83 & 15.0 & & Technician & 45 & 8.1 \\
\hline & Support - Financial & 47 & 8.5 & & Unspecified & 2 & .4 \\
\hline & Support - General & 29 & 5.2 & \multirow{8}{*}{ Education } & High school & 32 & 5.8 \\
\hline & Unspecified & 85 & 15.3 & & College & 12 & 2.2 \\
\hline \multirow{6}{*}{ Age } & $18-29$ & 88 & 15.9 & & Diploma & 81 & 14.6 \\
\hline & $30-39$ & 144 & 26.0 & & Degree & 118 & 21.3 \\
\hline & $40-49$ & 145 & 26.2 & & Honors' & 81 & 14.6 \\
\hline & $50-59$ & 126 & 22.7 & & Masters & 187 & 33.8 \\
\hline & $60-69$ & 44 & 7.9 & & Doctorate & 42 & 7.6 \\
\hline & $70+$ & 4 & .7 & & Unspecified & 1 & .2 \\
\hline \multirow{6}{*}{ Race } & Unspecified & 3 & .5 & \multirow{6}{*}{ Gender } & Male & 247 & 44.6 \\
\hline & White & 134 & 24.2 & & Female & 305 & 55.1 \\
\hline & Black & 193 & 34.8 & & Unspecified & 2 & .4 \\
\hline & Asian & 206 & 37.2 & & & & \\
\hline & Colored & 19 & 3.4 & & & & \\
\hline & Unspecified & 2 & .4 & & & & \\
\hline
\end{tabular}




\section{Cronbach (1951) Alpha Coefficient Test}

In order to test reliability the researcher applied the Cronbach (1951) Alpha Coefficient test. Table 2 provides the test results. All of the measurement constructs depicted an acceptable Alpha value (Cronbach 1951).

Table 2. Cronbach Alpha Test Results

\begin{tabular}{lcc}
\hline \multicolumn{1}{c}{ Measurement Construct } & Questions & Cronbach Alpha \\
\hline Trust & $1,6,8,17,30,32$ & 0.854 \\
Shared Norms and Values & $4,10,23,35$ & 0.759 \\
Attitude & $19,25,28$ & 0.763 \\
Perceived Norms & $3,15,24$ & 0.603 \\
Perceived Behavioral Control & $2,9,20,27$ (Deletion of questions 2 and 9 & 0.471 \\
& provided a Cronbach Apha of 0.683). & 0.839 \\
Intention to Share Tacit Knowledge & 18,26 & \\
\hline
\end{tabular}

\section{One-Sample t-test Results}

Table 3 provides the questions and One-Sample t-test results.

Table 3. One-Sample t-test Results

\begin{tabular}{|c|c|c|c|c|c|}
\hline No. & Questions & Mean & Std Dev. & $\begin{array}{c}\text { Sig. } \\
(2 \text {-tailed }) * *\end{array}$ & $\begin{array}{c}\text { Interpretation } \\
\text { Significant }\end{array}$ \\
\hline \multicolumn{6}{|c|}{$\begin{array}{l}\text { Trust } \\
\end{array}$} \\
\hline 1 & $\begin{array}{l}\text { My co-workers will always keep the promises they } \\
\text { make to me. }\end{array}$ & 3.18 & 1.085 & $<0.0005$ & Agreement \\
\hline 6 & I trust my co-workers & 3.40 & 1.180 & $<0.0005$ & Agreement \\
\hline 8 & My co-workers are reliable. & 3.44 & 1.038 & $<0.0005$ & Agreement \\
\hline 17 & $\begin{array}{l}\text { My co-workers and I have a sharing relationship. We } \\
\text { can freely share our ideas, feelings and hopes. }\end{array}$ & 3.44 & 1.085 & $<0.0005$ & Agreement \\
\hline 30 & $\begin{array}{l}\text { My co-workers are generally competent in what they } \\
\text { do at work. }\end{array}$ & 3.63 & 1.112 & $<0.0005$ & Agreement \\
\hline 32 & $\begin{array}{l}\text { My co-workers are generally knowledgeable about } \\
\text { their job. }\end{array}$ & 3.79 & .902 & $<0.0005$ & Agreement \\
\hline \multicolumn{6}{|c|}{ Shared Norms and Values } \\
\hline 4 & $\begin{array}{l}\text { There are people among my co-workers who give me } \\
\text { help, support and encouragement. }\end{array}$ & 4.08 & .894 & $<0.0005$ & Agreement \\
\hline 10 & $\begin{array}{l}\text { In general, my norms and values and the norms and } \\
\text { values held by my co-workers are very similar. }\end{array}$ & 3.02 & 1.079 & .694 & - \\
\hline 23 & $\begin{array}{l}\text { If I shared my problems with my co-workers, I know } \\
\text { that they will respond constructively and caringly. }\end{array}$ & 3.44 & 1.039 & $<0.0005$ & Agreement \\
\hline 35 & $\begin{array}{l}\text { If I shared my work experience and know-how with } \\
\text { my co-workers, they will be willing to share their } \\
\text { work experience and 'know-how' with me. }\end{array}$ & 3.53 & .947 & $<0.0005$ & Agreement \\
\hline \multicolumn{6}{|c|}{ Attitude towards Tacit Knowledge Sharing } \\
\hline 19 & $\begin{array}{l}\text { Sharing my work experience and know-how with my } \\
\text { co-workers is an enjoyable experience. }\end{array}$ & 3.83 & .880 & $<0.0005$ & Agreement \\
\hline 25 & $\begin{array}{l}\text { Sharing my work experience and 'know-how' with } \\
\text { my co-workers is valuable to me. }\end{array}$ & 3.97 & .794 & $<0.0005$ & Agreement \\
\hline 28 & $\begin{array}{l}\text { Sharing my work experience and 'know-how' with } \\
\text { my co-workers is good. }\end{array}$ & 4.14 & .712 & $<0.0005$ & Agreement \\
\hline \multicolumn{6}{|c|}{ Perceived Norms about Tacit Knowledge Sharing } \\
\hline 3 & $\begin{array}{l}\text { My boss thinks that I should share my work } \\
\text { experience and 'know-how' with my co-workers. }\end{array}$ & 3.70 & .961 & $<0.0005$ & Agreement \\
\hline 15 & $\begin{array}{l}\text { My co-workers think that I should share my work } \\
\text { experience and 'know-how' with other staff members. }\end{array}$ & 3.47 & .874 & $<0.0005$ & Agreement \\
\hline 24 & $\begin{array}{l}\text { Most people, whose opinion I value, would approve } \\
\text { of my sharing my work experience and 'know-how' } \\
\text { with my co-workers. }\end{array}$ & 3.95 & .715 & $<0.0005$ & Agreement \\
\hline
\end{tabular}




\begin{tabular}{|c|c|c|c|c|c|}
\hline No. & Questions & Mean & Std Dev. & $\begin{array}{c}\text { Sig. } \\
(2-\text { tailed }) * * \\
\end{array}$ & $\begin{array}{c}\text { Interpretation } \\
\text { Significant } \\
\end{array}$ \\
\hline \multicolumn{6}{|c|}{\begin{tabular}{|c|} 
Perceived Behavioral Control \\
\end{tabular}} \\
\hline 2 & $\begin{array}{l}\text { I have a great deal of personal control over the } \\
\text { amount of work experience and know-how that I } \\
\text { share with my co-workers. }\end{array}$ & 3.75 & .952 & $<0.0005$ & Agreement \\
\hline 9 & $\begin{array}{l}\text { Whether I share my work experience or 'know-how' } \\
\text { with my co-workers is entirely up to me. }\end{array}$ & 3.63 & .963 & $<0.0005$ & Agreement \\
\hline 20 & $\begin{array}{l}\text { I have the confidence to share my work experience } \\
\text { and know-how with my co-workers }\end{array}$ & 3.97 & .843 & $<0.0005$ & Agreement \\
\hline 27 & $\begin{array}{l}\text { I have the ability to share my work experience and } \\
\text { 'know-how' with my co-workers. }\end{array}$ & 4.12 & .669 & $<0.0005$ & Agreement \\
\hline \multicolumn{6}{|c|}{$\begin{array}{l}\text { Intention to Share Tacit Knowledge } \\
\end{array}$} \\
\hline 18 & $\begin{array}{l}\text { I intend to share my work experience and 'know-how' } \\
\text { with my co-workers more frequently in the future. }\end{array}$ & 3.75 & .852 & $<0.0005$ & Agreement \\
\hline 26 & $\begin{array}{l}\text { I intend to share expertise from my education and } \\
\text { training with my co-workers more frequently in the } \\
\text { future. }\end{array}$ & 3.86 & .798 & $<0.0005$ & Agreement \\
\hline
\end{tabular}

Structural Equation Modeling Results

'Goodness of Fit' Indices

Following the recommendations of Boomsma (2000) and Garver and Mentzer (1999) the following common indices were employed to assess the model fit to the data; the Chi square or CMIN/DF index, (Bentler, 1990), the Comparative Fit Index and the Root Mean Square Error of Approximation (RMSEA) index (Steiger, 1989; Steiger, 1990; Steiger and Lind, 1980). As Steiger (1990) developed the RMSEA index, his recommended indices were used in the assessment of the model fit. Table 4 provides the 'goodness of fit' indices used in this study.

Table 4. 'Goodness of Fit' Indices

\begin{tabular}{ll}
\hline \multicolumn{1}{c}{ 'Goodness of Fit' Indices } & \multicolumn{1}{c}{ Values (Recommended) } \\
\hline Chi Square & $(2-3)-$ for an acceptable fit, $<2$ for a good fit. \\
Comparative Fit Index & $>.9$ for an acceptable fit, $>.95$ for a good fit. \\
Root Mean Square Error of Approximation & $<.10$ for a good fit, $<.05$ for a very good fit, $<.01$ for an outstanding fit. \\
\hline
\end{tabular}

Confirmatory factors analysis, measurement model identification and measurement model fit to the data was performed. The measurement model was over-identified and the reliability and validity for the measurement model was confirmed. The estimated standardized factor loadings and reliability were all good. The reliability of each observed variable, as a measure of the latent variable, ranged from .33 to .76 . Each set of items designed to directly assess a given construct had a high degree of internal consistency, and the measures of the different constructs also exhibited discriminant validity. The measurement model revealed a good fit to the data. On this basis structural equation modeling was performed. The results for the structural model are presented as follows.

\section{$\underline{\text { Relational Social Capital - Path Diagram }}$} in Figure 2.

The structural model, path diagram with standardized coefficients for relational social capital is represented 
Figure 2. Relational Dimension of Social Capital - Path Diagram*

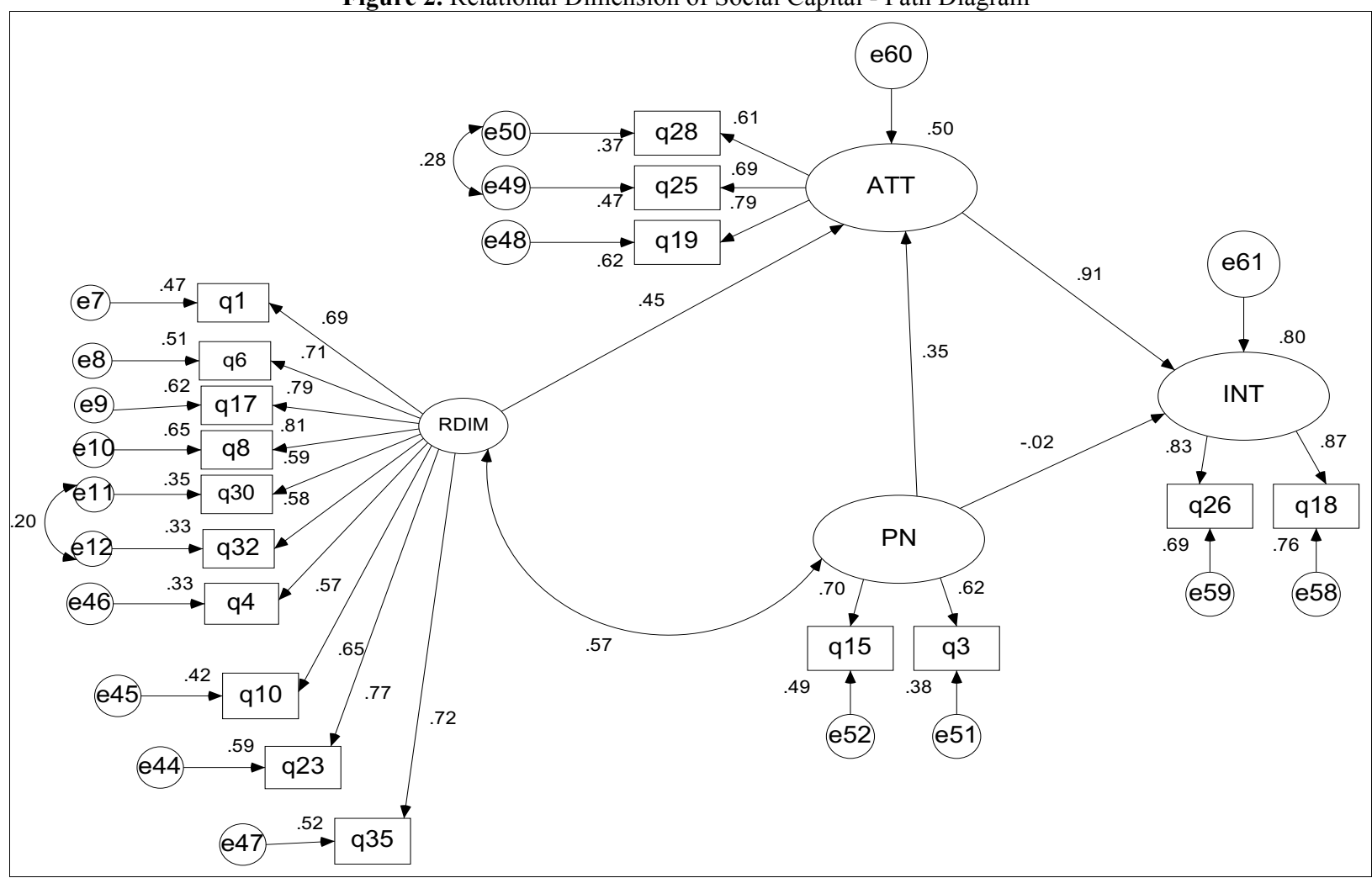

*Abbreviations: RDIM - Relational Dimension, ATT - Attitude, PN - Perceived Norms, INT - Intention.

\section{Model Fit Indices}

The ratio of $\chi^{2}$ (330.9) to the degrees of freedom (112) was 2.955. Since this value is $<3$, it indicates that the data fits the model globally. The comparative fit index was 0.950 . The root mean square residual of approximation was $0.059(.052 ; .067 . \mathrm{p}=.005)$. These fit indices indicate that there is a good fit to the data for the relational social capital model. This confirms that the studies theoretical model is a useful model for portraying the relationship between relational social capital and the individual's intention to share tacit knowledge.

\section{$\underline{\text { Factor Correlations }}$}

Table 5 represents the factor correlations for relational social capital. All of the measurement constructs were significantly correlated. Relational social capital was significantly correlated with the individual's intention to share tacit knowledge (.577). The highest correlation being between the individual's attitude towards tacit knowledge sharing and their intention to share tacit knowledge (.895).

Table 5. Relational Social Capital - Factor Correlations

\begin{tabular}{lcccc}
\hline \multicolumn{1}{c}{ Construct } & $\begin{array}{c}\text { Relational Social } \\
\text { Capital }\end{array}$ & Perceived Norms & Attitude & Intention \\
\hline Relational Social Capital & 1.000 & 1.000 & & \\
Perceived Norms & .566 & .602 & 1.000 & .895 \\
Attitude & .649 & .527 & .895 & 1.000 \\
Intention & .577 & & & \\
\hline
\end{tabular}




\section{$\underline{\text { Relational Social Capital - Hypotheses and Causal Effects }}$}

Table 6 represents the hypotheses and causal effects for relational social capital. Hypotheses 1, 2 and 4 were accepted and Hypothesis 3 was not accepted in the SEM analysis.

Table 6. Relational Dimension-Hypotheses and Causal Effects

\begin{tabular}{|c|c|c|c|c|c|}
\hline \multirow{2}{*}{ Outcome } & \multirow{2}{*}{ Determinant } & \multirow{2}{*}{ Hypothesis } & \multicolumn{3}{|c|}{ Causal Effects } \\
\hline & & & Direct & Indirect & Total \\
\hline \multirow[t]{2}{*}{ Attitude } & $\begin{array}{c}\text { Relational Social } \\
\text { Capital }\end{array}$ & $\begin{array}{l}\text { 1. Individuals who report a high level of } \\
\text { relational social capital (trust, shared norms and } \\
\text { values) will display a positive attitude towards } \\
\text { tacit knowledge sharing. }\end{array}$ & $.453 *$ & .000 & $.453^{*}$ \\
\hline & Perceived Norms & $\begin{array}{l}\text { 4. An individual's perceived norms about tacit } \\
\text { knowledge sharing positively influence their } \\
\text { attitude towards tacit knowledge sharing. }\end{array}$ & $.346^{*}$ & .000 & $.346^{*}$ \\
\hline \multirow[t]{3}{*}{ Intention } & $\begin{array}{l}\text { Relational } \\
\text { Dimension }\end{array}$ & ( & .000 & $.411^{*}$ & $.411^{*}$ \\
\hline & Perceived Norms & $\begin{array}{l}\text { 3. An individual's perceived norms about tacit } \\
\text { knowledge sharing positively influences their } \\
\text { intention to share tacit knowledge. }\end{array}$ & -.019 & $.313^{*}$ & $.295^{*}$ \\
\hline & Attitude & $\begin{array}{l}\text { 2. An individual's positive attitude towards tacit } \\
\text { knowledge sharing positively influences their } \\
\text { intention to share tacit knowledge. }\end{array}$ & $.906^{*}$ & .000 & $.906^{*}$ \\
\hline
\end{tabular}

* Statistically significant at $\alpha=0.01$

\section{DISCUSSION AND RECOMMENDATIONS}

\section{Discussion}

According to the global model fit indices and the detailed model fit indicators; the initial hypothesized model was a poor fit to the data. It was found that the reasoned action variable of perceived behavioral control was not significant for predicting an individual's intention to share tacit knowledge in the initial hypothesized model and thus was eliminated in the revised study model. In addition, perceived norms loaded more strongly onto attitude towards the sharing of tacit knowledge than it did onto the individual's intention to share tacit knowledge. Thus, some aspects of the findings in this study were contradictory to Fishbein and Ajzen's (2010) findings and highlight specific problems with their theory in relation to tacit knowledge sharing behavior. Specifically, with regard to the application of SEM analysis in reasoned action models and the role of perceived behavioural control and perceived norms in tacit knowledge sharing behavior.

On the other hand, the revised research model which excluded perceived behavioral control was found to be a good fit to the data. This finding confirmed that there is a positive correlation between affect and cognitivebased trust, shared norms and values, social norms, norms of social support, norms of reciprocity and the individual's attitude towards tacit knowledge sharing. Relational social capital had a direct causal effect on the individual's attitude towards tacit knowledge sharing (Table 6 - .453.). With regard to the reasoned action variables, in contrast to Fishbein and Ajzen's (2010) findings, there was not a direct effect of perceived norms on the individual's intention to share tacit knowledge. Perceived norms had a direct causal effect on the individual's attitude towards tacit knowledge sharing (Table 6 - .346). The individual's perceived norms were thus mediated by their attitude towards tacit knowledge sharing. There was a strong, significant direct effect of the individual's attitude towards tacit knowledge sharing on the individual's intention to share tacit knowledge (Table 6 - .906). Perceived norms, though, had a non-significant, negative effect on intention $\{$ Table $6-(-.019)\}$. Furthermore, for each dimension of relational social capital (trust, shared norms and values) the individual's attitude towards tacit knowledge sharing acted as a mediating variable for the individual's intention to share tacit knowledge.

Thus, this study developed a new model of tacit knowledge sharing behavior. The results satisfied the core hypothesis which was that an individual's tacit knowledge sharing intentions can be analyzed within a relational social capital and a reasoned action framework and that relational social capital positively affects an individual's 
attitude towards the sharing of tacit knowledge, which in turn, positively affects an individual's intention to share tacit knowledge (Fishbein and Ajzen, 2010) within certain limitations (for example, the poor results for perceived behavioral control).

\section{Recommendation}

This study suggests that in order to establish a knowledge-based culture that constantly generates new knowledge in a university, it is important to a) uncover and understand the beliefs, motivations and attitudes of individual staff members towards tacit knowledge sharing and b) understand the relationships and processes involved in individual tacit knowledge sharing behavior within the university. Management must consciously cultivate social relationships and interpersonal interactions of employees, rather than expecting them to arise organically from day-to-day work. In particular, fostering a work context characterized by high levels of trust, shared norms and values is likely to nurture the mutual social exchange relationships that are important in driving knowledge sharing intentions. By making social capital predication a more overt mission and actively promoting social capital and tacit knowledge sharing behavior, universities can become more relevant and advance the development of intellectual capital.

Furthermore, this study highlights that additional scholarly work is required to understand the role of the variables in the theory of reasoned action, particularly, the individual's attitude towards the behavior in question and, specifically, the role of perceived behavioral control in tacit knowledge sharing behaviour.

\section{CONCLUSION}

This study analyzed tacit knowledge sharing behavior within a relational social capital framework, in a South African University of Technology. It provided theoretical and empirical insights into the social capital and reasoned action factors which predict an individual's intention to share tacit knowledge. It contributed to expanding the research base by providing a new theoretical model which is applicable to the sharing of tacit knowledge in universities.

The findings of this study provide evidence of important predictors and mediators of tacit knowledge sharing behavior which will inform scholarly models of the sharing of tacit knowledge. It further contributes to clarifying the specific pattern of relationships and pathways among the tacit knowledge sharing intention antecedents. Finally, as universities are in the business of creating and sharing knowledge, the improved understanding of the reasons why tacit knowledge is or is not shared at the individual level, provided by this study, enables action to be taken to improve business and managerial strategic practices to enhance the development of intellectual capital.

Given the importance of tacit knowledge sharing in today's world - and even more so in tomorrow's world it is hoped that these findings will be useful to others engaged in scholarship aimed at enriching our collective understanding regarding tacit knowledge sharing within academia and across organizational communities.

\section{AUTHOR INFORMATION}

Carol Smith is a Lecturer at the Durban University of Technology. She has thirteen years of experience in teaching and research at a university level. Prior to this, she had extensive human resource management and training experience in the wholesale and retail industry. She holds a B.A. Honor's degree in Social Work (Wits), a Master's Degree in Women's Studies (UKZN), a Master's Degree in Business Administration (University of Wales) and a Doctorate in Business Administration (DUT). Her main research interests are business management, social capital, social networking and knowledge management.

Marie de Beer was awarded her Ph.D. in 2001. She has spent eighteen years at Durban University of Technology, South Africa, as a Senior Lecturer in the Department of Financial Accounting and later as a Research Coordinator for the Faculty of Commerce. She is now a Research Associate for the Department of Entrepreneurial Studies and Management in the Faculty of Management Sciences. Her core duties are publishing, supervision and promoting 
postgraduate degrees. Her main research interests are research, development and application of ICT in academic and commercial management on which she has presented papers at international conferences and published in international journals.

Roger Mason is an Honorary Research Professor at Durban University of Technology. Prior to this he was Professor of Marketing and previously had experience in marketing in the motor industry and consulting in marketing and management to a wide variety of industries. He obtained B.A. and Ph.D. degrees from Rhodes University and an M.B.L. degree and a Post Graduate Diploma in Marketing Research and Advertising from UNISA, plus diplomas in Post Graduate Higher Education Teaching and Learning, and in Marketing. His research focuses on management, strategy, retail and marketing, using a cross disciplinary approach involving the chaos and complexity sciences. He has published widely in international and local journals.

\section{REFERENCES}

Adler, P. S., and Kwon, S.W. (2002). Social capital: prospects for a new concept. Academy of Management Review, 27(1), $17-40$.

Ajzen, I. (1991). The theory of planned behavior. Organizational Behavior and Human Decision Processes, 50(2), 179211. Doi: 10.1016/0749-5978(91)90020-t

Allport, G. W. (1935). Attitudes. A handbook of social psychology. Worcester, MA, US: Clark University Press.

Anderson, J. C., \& Gerbing, D. W. (1988). Structural equation modeling in practice: A review and recommended two-step approach. Psychological Bulletin, 103(3), 411.

Armistead, C., \& Meakins, M. (2002). A framework for practising knowledge management. Long Range Planning, 35(1), 49-71.

Baldwin, T. T., Pierce, J. R., Joines, R. C., \& Farouk, S. (2011). The elusiveness of applied management knowledge: a critical challenge for management educators. Academy of Management Learning \& Education, 10(4), 583-605.

Bartol, K. M., \& Srivastava, A. (2002). Encouraging knowledge sharing: The role of organizational reward systems. Journal of Leadership \& Organizational Studies, 9(1), 64-76.

Bentler, P. M. (1990). Comparative fit indexes in structural models. Psychological Bulletin, 107(2), 238-246.

Bock, G. W., Zmud, R. W., Kim, Y. G., \& Lee, J. N. (2005). Behavioral intention formation in knowledge sharing: Examining the roles of extrinsic motivators, social-psychological forces, and organizational climate. MIS Quarterly, 87-111.

Bolino, M. C., Turnley, W. H., \& Bloodgood, J. M. (2002). Citizenship behavior and the creation of social capital in organizations. Academy of Management Review, 27(4), 505-522.

Boomsma, A. (2000). Reporting analyses of covariance structures. Structural Equation Modeling, 7(3), 461-483.

Carley, K. (1991). A theory of group stability. American Sociological Review, 56, 331-354.

Chang, M. K. (1998). Predicting unethical behavior: A comparison of the theory of reasoned action and the theory of planned behavior. Journal of Business Ethics, 17(16), 1825-1834.

Chow, W. S., \& Chan, L. S. (2008). Social network, social trust and shared goals in organizational knowledge sharing. Information \& Management, 45(7), 458-465. DOI: 10.1016/j.im.2008.06.007

Cialdini, R. B. (2007). Descriptive social norms as underappreciated sources of social control. Psychometrika, 72(2), 263268.

Cronbach, L. J. (1951). Coefficient alpha and the internal structure of tests. Psychometrika, 16(3), 297-334.

Davenport, T. H. (1998). Putting the enterprise into the enterprise system. Harvard Business Review, 76(4), 121-131.

Dyer, J., \& Nobeoka, K. (2002). Creating and managing a high performance knowledge-sharing network: the Toyota case. Retrieved from 2 Oct. 2012, http://www.hdl.handle.net/1721.1/1441.

Fishbein, M., \& Ajzen, I. (1981). On construct validity: A critique of Miniard and Cohen's paper. Journal of Experimental Social Psychology, 17(3), 340-350.

Fishbein, M., \& Ajzen, I. (2010). Predicting and changing behaviour. The reasoned action approach. New York: Psychology Press.

Garver, M. S., \& Mentzer, J. T. (1999). Logistics research methods: employing structural equation modeling to test for construct validity. Journal of Business Logistics, 20, 33-58.

Godin, G., \& Kok, G. (1996). The theory of planned behaviour: a review of its applications to health-related behaviours. American Journal of Health Promotion, 11(2), 87-98.

Hazleton, V., \& Kennan, W. (2000). Social capital: reconceptualising the bottom line. Corporate Communications: An International Journal, 5(2), 81-87. 
Inkpen, A. C., \& Pien, W. (2006). An examination of collaboration and knowledge transfer: China-Singapore Suzhou Industrial Park. Journal of Management Studies, 43(4), 779-811.

Kline, R. (2005). Principles and practice of structural equation modeling. Guilford. New York, 366.

Kramer, R. M. (1999). Trust and distrust in organizations: Emerging perspectives, enduring questions. Annual Review of Psychology, 50(1), 569-598.

Kramer, R. M., \& Goldman, L. (1995). Helping the group or helping yourself? Social motives and group identity in resource dilemmas. Social dilemmas: perspectives on individuals and groups, 49-67.

Kurland, N. B. (1995). Ethical intentions and the theories of reasoned action and planned behavior. Journal of Applied Social Psychology, 25(4), 297-313.

Lam, A. (2000). Tacit knowledge, organizational learning and societal institutions: an integrated framework. Organization Studies, 21(3), 487-513.

Leana, C. R., \& Van Buren, H. J. (1999). Organizational social capital and employment practices. Academy of Management Review, 24(3), 538-555.

Leonard-Barton, D. (1995). Wellsprings of knowledge: Building and sustaining the sources of innovation: Harvard Business Press.

Lewis, J. D., \& Weigert, A. (1985). Trust as a social reality. Social Forces, 63(4), 967-985.

Mathieson, K. (1991). Predicting user intentions: comparing the technology acceptance model with the theory of planned behaviour. Information Systems Research, 2(3), 173-191.

Nahapiet, J., \& Ghoshal, S. (1998). Social capital, intellectual capital and the organisational advantage. Academy of Management Review, 23(2), 242-266.

Nelson, K. M., \& Cooprider, J. G. (1996). The contribution of shared knowledge to IS group performance. MIS Quarterly, 409-432.

O'Dell, C., \& Grayson, C. J. (1998). If only we knew what we know: identification and transfer of internal best practices. California Management Review, 40(3), 154-174.

Rousseau, D. M., Sitkin, S. B., Burt, R. S., \& Camerer, C. (1998). Not so different after all: A cross-discipline view of trust. Academy of Management Review, 23(3), 393-404.

Schurr, P. H., \& Ozanne, J. L. (1985). Influences on exchange processes: buyers' preconceptions of a seller's trustworthiness and bargaining toughness. Journal of Consumer Research, 939-953.

Seonghee, K., \& Boryung, J. (2008). An analysis of faculty perceptions: Attitudes toward knowledge sharing and collaboration in an academic institution. Library \& Information Science Research, 30(4), 282-290.

Shepherd, G. J., \& O'Keefe, D. J. (1984). Separability of attitudinal and normative influences on behavioural intentions in the Fishbein-Ajzen model. The Journal of Social Psychology, 122(2), 287-288.

Shimp, T. A., \& Kavas, A. (1984). The theory of reasoned action applied to coupon usage. Journal of Consumer Research, 795-809.

Steiger, J. H. (1989). EzPATH: Causal Modeling: a Supplementary Module for SYSTAT and SYGRAPH: PC-MS-DOS, Version 1.0: Systat.

Steiger, J. H. (1990). Structural model evaluation and modification: An interval estimation approach. Multivariate Behavioural Research, 25(2), 173-180.

Steiger, J. H., \& Lind, J. C. (1980). Statistically based tests for the number of common factors. Paper presented at the annual meeting of the Psychometric Society, Iowa City, IA.

Van den Putte, B. (1993). On the theory of reasoned action. Unpublished doctoral dissertation. University of Amsterdam.

Van den Putte, B., \& Hoogstraten, J. (1997). Applying structural equation modeling in the context of the theory of reasoned action: Some problems and solutions. Structural Equation Modeling: A Multidisciplinary Journal, 4(4), 320-337.

Venkatesh, V., \& Davis, F. D. (2000). A theoretical extension of the technology acceptance model: Four longitudinal field studies. Management Science, 186-204.

Von Krogh, G. (1998). Care in. California Management Review, 40(3), 133.

Wasko, M. M. L., \& Faraj, S. (2005). Why should I share? Examining social capital and knowledge contribution in electronic networks of practice. MIS Quarterly, 35-57.

Weston, R., \& Gore, P. A. (2006). A brief guide to structural equation modeling. The Counseling Psychologist, 34(5), 719751.

Yang, J. T. (2010). Antecedents and consequences of knowledge sharing in international tourist hotels. International Journal of Hospitality Management, 29(1), 42-52.

Yang, S. C., \& Farn, C.K. (2009). Social capital, behavioural control, and tacit knowledge sharing - A multi-informant design. International Journal of Information Management, 29(3), 210-218. 


\section{NOTES}

